\title{
TRANSITIONS INTO PARENTHOOD: EXAMINING THE COMPLEXITIES OF CHILDREARING
}




\section{CONTEMPORARY PERSPECTIVES IN FAMILY RESEARCH}

\section{Series Editor: Sampson Lee Blair}

\section{Recent Volumes:}

Volume 1: $\quad$ Through the Eyes of the Child Re-visioning Children as Active Agents of Family Life - Edited by Michael Abrams, Johnson Matthey, B. A. Murrer, Felix M. Berardo, and Constance L. Shehan, 2000

Volume 2: $\quad$ Families, Crime and Criminal Justice Charting the Linkages - Edited by Greer Litton Fox and Michael L. Benson, 2000

Volume 3: $\quad$ Minding the Time in Family Experience Emerging Perspectives and Issues - Edited by Kerry Daly, 2001

Volume 4: $\quad$ Intergenerational Ambivalences New Perspectives on Parent-Child Relations in Later Life - Edited by Karl A. Pillemer and Kurt K. Luscher, 2003

Volume 5: $\quad$ Families in Eastern Europe - Edited by Mihaela Robila, 2004

Volume 6: $\quad$ Economic Stress and the Family - Edited by Sampson Lee Blair, 2012

Volume 7: Visions of the 21st Century Family: Transforming Structures and Identities - Edited by Patricia Neff Claster and Sampson Lee Blair, 2013

Volume 8A: Family Relationships and Familial Responses to Health Issues Edited by Jennifer Higgins McCormick and Sampson Lee Blair, 2014

Volume 8B: Family and Health: Evolving Needs, Responsibilities, and Experiences - Edited by Sampson Lee Blair and Jennifer Higgins McCormick, 2014

Volume 9: Violenceand Crimein the Family: Patterns, Causes, and ConsequencesEdited by Sheila Royo Maxwell and Sampson Lee Blair, 2015

Volume 10: Divorce, Separation, and Remarriage: The Transformation of FamilyEdited by Giovanna Gianesini and Sampson Lee Blair 2017

Volume 11: Intimate Relationships and Social Change: The Dynamic Nature of Dating, Mating, and Coupling - Edited by Christina L. Scott and Sampson Lee Blair 2018

Volume 12: $\quad$ Fathers, Childcare and Work - Edited By Arianna Santero and Rosy Musumeci, 2018

Volume 13: The Work-Family Interface: Spillover, Complications, and Challenges - Edited by Sampson Lee Blair and Josip Obradović, 2018

Volume 14: Childbearing and the Changing Nature of Parenting: The Contexts, Actors, and Experiences of Having Children - Edited by Rosalina Pisco Costa and Sampson Lee Blair, 2019 


\section{EDITORIAL BOARD}

Anja-Kristin Abendroth

Bielefeld University, Germany

Clarence M. Batan

University of Santo Tomas, Philippines

Eli Buchbinder

University of Haifa, Israel

Yu-Hua Chen

National Taiwan University, Taiwan

Patricia Neff Claster

Edinboro University, USA

Teresa M. Cooney

University of Colorado-Denver, USA

Rosalina Pisco Costa

University of Évora, Portugal

Alda Britto da Motta

Federal University of Bahia, Brazil

Olufemi Adeniyi Fawole

University of Ilorin, Nigeria

Giovanna Gianesini

University of Bologna, Italy
Ana Josefina Cuevas Hernandez

University of Colima, Mexico

Bryndl Hohmann-Marriott

University of Otago, New Zealand

Cardell K. Jacobson

Brigham Young University, USA

Josip Obradović

University of Zagreb, Croatia

Matthias Pollman-Schult

Social Science Research Center Berlin,

Germany

Ria Smit

University of Johannesburg, South

Africa

Helen M. Stallman

University of South Australia,

Australia

Fleur Thomése

$V U$ University, Amsterdam,

The Netherlands 
This page intentionally left blank 
CONTEMPORARY PERSPECTIVES IN FAMILY

RESEARCH VOLUME 15

\title{
TRANSITIONS INTO PARENTHOOD: EXAMINING THE COMPLEXITIES OF CHILDREARING
}

\author{
EDITED BY \\ SAMPSON LEE BLAIR \\ State University of New York at Buffalo, USA

\section{ROSALINA PISCO COSTA} \\ Universidade de Évora, Portugal
}

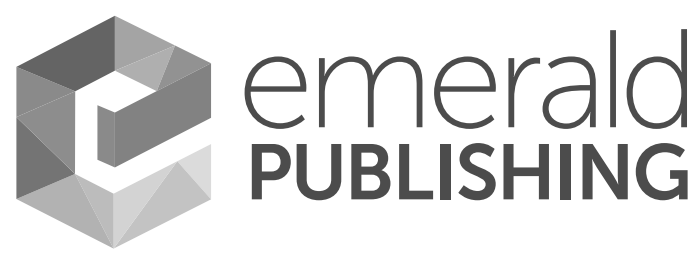

United Kingdom - North America - Japan India - Malaysia - China 
Emerald Publishing Limited

Howard House, Wagon Lane, Bingley BD16 1WA, UK

First edition 2020

Copyright (C) 2020 Emerald Publishing Limited

Reprints and permissions service

Contact: permissions@emeraldinsight.com

No part of this book may be reproduced, stored in a retrieval system, transmitted in any form or by any means electronic, mechanical, photocopying, recording or otherwise without either the prior written permission of the publisher or a licence permitting restricted copying issued in the UK by The Copyright Licensing Agency and in the USA by The Copyright Clearance Center. Any opinions expressed in the chapters are those of the authors. Whilst Emerald makes every effort to ensure the quality and accuracy of its content, Emerald makes no representation implied or otherwise, as to the chapters' suitability and application and disclaims any warranties, express or implied, to their use.

British Library Cataloguing in Publication Data

A catalogue record for this book is available from the British Library

ISBN: 978-1-83909-222-0 (Print)

ISBN: 978-1-83909-221-3 (Online)

ISBN: 978-1-83909-223-7 (Epub)

ISSN: 1530-3535 (Series)



SOQAR certified

Management System,

awarded to Emerald

for adherence to

Environmental

ISOQAR

standard

REGISTERED

ISO 14001:2004.

Certificate Number 1985

ISO 14001

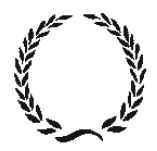

INVESTOR IN PEOPLE 


\section{CONTENTS}

About the Contributors

$i x$

Preface

$x v i i$

Chapter 1 Young Adult Parents' Work-Family Conflict: The Roles of Parenting Stress and Parental Conflict Amira L. Allen, Wendy D. Manning, Monica A. Longmore and Peggy C. Giordano

Chapter 2 Experiences of Family and Social Support during the Transition to Motherhood among Mothers of Biracial and Monoracial Infants

Roudi Nazarinia Roy, Yolanda Mitchell, Anthony James, Byron Miller and Jessica Hutchinson

Chapter 3 Narratives from Community-based Organization Staff and Black and Coloured Mothers in South Africa:

A Qualitative Study on the Impact of Participation in Parenting Programs on Maternal Behaviors

Simone Martin-Howard

Chapter 4 For Us or the Children? Exploring the Association between Coparenting Trajectories and Parental Commitment Heidi M. Williams

Chapter 5 Mediating Effects of Maternal Gatekeeping on Nonresident Black Fathers' Paternal Stressors

Katrina A. R. Akande and Claudia J. Heath

Chapter 6 A Conceptual and Methodological Exploration of the Cognitive Processes Associated with Mindful Parenting: Reflections on Translating Theory to Practice

Kishani Townshend and Nerina Caltabiano 
Chapter 7 In Which Language(s) Do You Parent?

How Language(s) Used by Migrant Parents Influence

the Realization of Parenting Functions

Maria Siemushyna and Andrea S. Young

Chapter 8 Co-sleeping as a Developmental Context and its Role in the Transition to Parenthood

Elaine S. Barry

Chapter 9 Mother-Child Relationships and Depressive Symptoms in the Transition to Adulthood: An Examination of Racial and Ethnic Differences

Xing Zhang

Chapter 10 Parenting in Three-generation Taiwanese Families: The Dynamics of Collaboration and Conflicts Yi-Ping Shih

Index 